\title{
Self-Paced Formative Assessment: Concept and Applications in Learning ESL Vocabulary
}

\author{
Gayathree Chandran, Harwati Hashim* \\ Faculty of Education, Universiti Kebangsaan Malaysia, Bangi, Malaysia \\ Email: ^harwati@ukm.edu.my
}

How to cite this paper: Chandran, G., \& Hashim, H. (2021). Self-Paced Formative Assessment: Concept and Applications in Learning ESL Vocabulary. Creative Education, 12, 140-150.

https://doi.org/10.4236/ce.2021.121010

Received: December 7, 2020

Accepted: January 17, 2021

Published: January 20, 2021

Copyright $\odot 2021$ by author(s) and Scientific Research Publishing Inc. This work is licensed under the Creative Commons Attribution International License (CC BY 4.0).

http://creativecommons.org/licenses/by/4.0/

(c) (i) Open Access

\begin{abstract}
The concept paper discusses the self-paced formative assessment in the context of the ESL classroom vocabulary instruction. In this paper, the concept is discussed along with the history and emergence of language learning strategies from the core of language theories. The explorations of past studies reveal the importance of an assessment method that helps learners identify their needs and their preferred learning strategies. The self-paced assessment technique is described as self-directed and important in helping learners acquire vocabulary more effectively. The study focuses on past studies that document the implications, issues of employing self-paced assessment in the second language classroom, the advantage and constrains on self-paced assessment in context of second language classroom. Primary ideas like word recognition, the three-tier model and word meanings are discussed to elaborate the concept of self-paced assessment and how it should work in vocabulary instruction. The major implications of this study are in the designing and implementation of second language lessons where teachers should focus more on providing room for learners to direct their assessments. As for future researches, a sound methodology for experimentation is recommended to fully explore the feasibility of self-paced assessments in the ESL classroom. It is believed that self-paced formative assessment would enhance vocabulary mastery among ESL learners. Hence, this paper explains how self-paced formative assessment assists in learning vocabulary.
\end{abstract}

\section{Keywords}

Self-Paced Formative Assessment, Learning, Vocabulary

\section{Introduction}

ESL (English as a Second Language) has evolved along with the global changes in 
general education. The shift towards $21^{\text {st }}$ century education and focus on higher order thinking skills boosted the need for language teaching that helped learners to become competitive and more skillful. ESL encompasses a limitless embodiment in the education system because it is a language that transcends the different disciplines that exist in education, makes it highly adaptive and important at the same time. In addressing the needs of the fourth industrial revolution, countries have restructured their education systems and more emphasis on Science, Technology, Engineering and Mathematics (STEM) based education has also caused the importance of ESL to rise significantly (Yunus \& Sukri, 2017).

Communicative language teaching quickly rose to replace more conventional methods which focused heavily on memory strategies such as the audio-lingual method (Oxford \& Burry-Stock, 1995). Halliday (as cited in Halliday, Matthiessen, \& Matthiessen, 2014) put forth the earliest theories that proposed the importance of meaning rather than form in language teaching. The theory suggests the importance of the social setting in which a language is used, and the function of the language is seen as the core of the discourse (Halliday, Matthiessen, \& Matthiessen, 2014). While both perspectives give significant priorities to vocabulary learning, the evolution of ESL has also impacted vocabulary learning in many ways. The language learning strategies that emerged from core theories like the audio-lingual methods or the communicative approached reflect how vocabulary is taught and learned in the ESL classroom (Gu \& Johnson, 1996).

The transformation in vocabulary learning is described by Kreidler (1979) who believed that the concept of memorising word lists as the core of language learning is irrelevant. A more meaningful way of learning vocabulary is by practicing language in the real-life context. Language learning and learning vocabularies are inseparable because vocabularies make up a language (Kreidler, 1979). Vocabulary learning has been associated with language learning strategies which have evolved from time to time. Ellis (2010) believed that there needs to be a set of procedures to acquire language components. Rubin (1981) described the procedures in language learning as devices or tools learners use to learn the different components in language. These definitions are significant in understanding how learners acquire vocabulary in ESL classrooms.

Assessment of vocabulary learning is key in the ESL classroom and the core of any technique or strategy is to employ reliable tests that can project the actual learning that has been achieved. Vocabulary acquisition is related to tests that are often related to memory strategies as proposed by theorists who explored general language learning strategies which lead to vocabulary acquisition models which involve tests that evaluate reading comprehension as a way to measure vocabulary acquisition. Therefore, in this concept paper about self-paced assessment in vocabulary learning, models of vocabulary acquisition, tests related to acquisition of vocabulary in the ESL classroom and how vocabulary determines the pedagogical implications in Malaysian classrooms will be discussed in-depth. Below conceptual paper will discuss on literature review focus on vo- 
cabulary and self-paced assessment, then pedagogical implications which is training of ESL teacher and stakeholders, end with conclusion.

\section{Literature Review}

In this section, definitions of vocabulary learning in the ESL classroom, various models of vocabulary acquisition and past researches in the context of self-paced assessment are discussed in detail.

\subsection{Vocabulary}

Vocabulary acquisition has been described as the key to learning any language in the world. In González Fernández and Schmitt (2017) vocabulary has been described as crucial components that influence the productive and receptive skills in a language. This means that vocabulary learning influences the reading, writing, listening and speaking skills which determine the level of proficiency in any language (Moses \& Mohamad, 2019). In that sense, the vocabulary has been defined as key in helping learners achieve better reading in a new language.

Wang and Yamat (2019) stated that the English vocabulary can be divided into ten groups of speech which are known as word classes like nouns, adjectives, adverbs and prepositions. Their study explored the problems of the ESL classroom in Malaysia which mainly occurred due to the over-emphasis of rote memorisation in vocabulary instruction. The 'Three-Tier Model' proposed by Beck, McKeown and Kucan (2002) dissects vocabulary into three different categories and defines vocabulary as the multi-level tiers that make up a certain language. The first tier in the model is basic words which contain sight words and function words. The second tier contains academic words, and the third tier contains content-specific words. This model plays a significant role in understanding how teachers can evaluate and assess the learning of vocabulary in the classroom because the model breaks down vocabulary into three different categories (Guo, Wang, Hall, Breit-Smith, \& Busch, 2016).

In a magnificent effort to document English vocabulary, Dale and O'Rourke (1981) re-ported a large list of words which are used for direct testing of vocabulary acquisition. The 20 -year longitudinal study was conducted with about 200 students for each grade in the United States. This resulted in a vocabulary test that is widely used in assessing achievement of vocabulary till today. Vocabulary assessment at this point is crucial to categorise learners' levels which is used to design appropriate lessons that would result in the increased acquirement of vocabulary among learners (Goldstein, Ziolkowski, Bojczyk, Marty, Schneider, Harpring et al., 2017).

\subsection{Self-Paced Assessment}

Self-paced assessment is related to the self-regulated nature of formative assessment which defines the learners' autonomy in designing, conducting and recording their assessments independently (Maldonado-Mahauad, Pérez-Sanagustín, 
Moreno-Marcos, Alario-Hoyos, Muñoz-Merino, \& Delgado-Kloos, 2018). A major part of self-paced assessment comes from the studies related to formative assessment, mixed ability learners, multiple intelligence, and differentiated learning (Maldonado-Mahauad, Pérez-Sanagustín, Moreno-Marcos, Alario-Hoyos, Muñoz-Merino, \& Delgado-Kloos, 2018). In layman terms, the self-paced formative assessment can be a self-directed test that allows the learner to test according to his or her rate of learning. This type of assessment is instrumental in further strengthening concepts of class-based assessment and differentiated learning strategies which have become important components of the $21^{\text {st }}$ century ESL classroom in Malaysia.

In expanding the idea of self-paced formative assessment in vocabulary learning, the perceptions and contexts which influence the learning of vocabulary in each individual learner needs to be discussed. This will provide a clearer view of the needs and effectiveness of a self-paced formative assessment in the ESL classroom. In contextual acquisition of vocabulary, a student constructs the meaning of a word and then completely acquires a certain vocabulary by deriving information from the context in which the word is used (Brysbaert, Stevens, \& Van Assche, 2018). This is crucial in understanding how the learners need self-paced assessment to learn vocabulary better.

Formative assessment is crucial in reporting information that is vital for teachers because the information can be used to design more effective lessons in the future (Haris, Yunus, \& Badusah, 2017). In defining self-paced assessment, Ketabi and Ketabi (2014) reiterate that it is a process of allowing learners to define their progress by participating in a range of activities in the classroom. These activities can be in the form of tasks and projects which give them the opportunity to apply what they have learned, and the self-paced assessment helps them to keep track of their learning by self-evaluating. This also directly influences the teachers' performance as teachers can decide to employ techniques that suit every learner's particular needs.

A good example of understanding the ESL classroom is to understand the mixed ability nature of a large group of students. Many factors contribute to learner preferences in the ESL classroom and according to Lee and Pulido (2017), vocabulary instruction needs to be conducted in line with the learner preferences. Formative assessment in vocabulary learning guides teachers to understand the learner's preferences better. Lim, Eng, Mohamed and Ismail (2018) agreed that the fundamental issue in the Malaysian primary ESL classroom is management of mixed-ability learners where experience and proficiency levels become primary determiners which indicate the level of learning achieved by each student. The role of formative assessment, such as self-paced formative assessment in vocabulary instruction is to ensure that each learner is able to self-report their learning and these reports would be informative to teachers.

Learner's self-assessment has been given a fresh new role in the new curriculum framework in Malaysia with more emphasis for differentiated learning. The 
main purpose for this is to allow learners to gauge their learning and contribute vital information to their teachers to create lessons that can match their abilities. For example, there are rating scales, project work, task-based assessments, journal writing, 'hot-seat' techniques and reflection circles which are suggested in the curriculum which focuses on formative assessment. This is where self-paced assessment in vocabulary instruction is defined as individualised or customised testing (Kepinska, de Rover, Caspers, \& Schiller, 2017).

Formative assessment in general has become increasingly important and relevant to the global educational needs. The advantages of formative assessment like differentiated learning, teacher's feedback and teaching reflection and motivation in the language classroom are obviously catering to the shift in language instruction. In general, formative assessments come with a few challenges which are comprehensibility and mixed ability classroom mainly related to implementation and practicality in the reality of teaching of learning. Self-paced assessment in specific also has its own issues when it comes to implementation in the ESL classroom.

\subsubsection{Differentiated Learning}

Using self-paced assessment in the ESL classroom especially when teaching vocabulary allows the teachers to check the students' understanding for each new word based on their own pace. According to Stover, Yearta and Harris (2016) the concept of differentiated learning comes from the theory of multiple intelligences which defines how each learner has their own method of learning. Self-paced assessment in the ESL classroom helps the teacher to project a lesson in the way best preferred by each learner. For example, if a learner learns better through reading, then more reading materials can be given to the learner. Therefore, it is important that self-paced assessment is used so that teachers can gather valuable information to conduct differentiated learning successfully.

\subsubsection{Teachers' Feedback and Teaching Reflection}

Self-paced formative assessment for vocabulary instructions provides vital information for teachers which could help them structure their pedagogy in the future. Sardareh (2018) states that feedback is a major component in formative assessment because useful feedback drives the teacher to understand what the learner actually needs. Feedback information is crucial in filling up gaps of learning (Sardareh, 2018) and one gap in the ESL classroom is the different rate of learning. For instance, if one student learns the meaning of the word "supper" in day one of a lesson and another student takes three more lessons to grasp the meaning of the word, the self-paced assessment serves as a documented report which helps the teacher to design all future lessons to be more effective for both learners.

\subsubsection{Motivation}

The motivational factors are highly significant in the ESL classroom because it influences learners' perceptions and self-efficacy in the long run. According to 
Jalani and Hashim (2020), self-paced assessment can be pivotal in ensuring that learners get a constant boost of self-confidence in learning vocabulary in the ESL classroom. In one of the earlier studies in vocabulary instruction, Gu and Johnson (1996) designed a questionnaire known as the Vocabulary Learning Questionnaire to assess the preferred strategies used by the learners which is a form of self-paced assessment which continuously helped learners to check their learning, record their progress and most importantly motivate them from one lesson to the other. Zulkiflei, Yunus and Hashim (2017) found that positive perceptions enhanced the learning of ESL in Malaysia and the use of formative assessments in the classroom can work as a tool that boosts the learner's morale.

\subsubsection{Comprehensibility}

When dealing with a group of second language learners, assessing their learning becomes a conflict because assessment needs to be done in a way that they can understand. The issue of comprehensibility has been discussed in Nagy, Herman and Anderson (1985) and Landauer and Dumais (1997) when vocabulary tests were conducted to study the rate of vocabulary learning among learners. The studies found that it was challenging to assess learners in the English language if they have not mastered the language fully. Therefore, there have been calls to design self-paced assessments in their own mother tongue to avoid the issue of comprehensibility and ambiguity. Kintsch (2007) points out this issue when using the Word Maturity concept to assess vocabulary acquisition among second language learners. However, this can be eased with the use of assessment modes which are accompanied by more aids such as pictures or audio and most importantly, formative strategies that embed assessment within tasks in the classroom itself.

\subsubsection{Mixed-Ability Classroom}

As much as self-paced assessment would be highly beneficial to provide better teaching and learning for a mixed ability classroom, the problem is that it may not be realistic to be conducted in the real classroom. Broadbent, Panadero and Boud (2018) admitted that it is not practical to implement formative assessment in the actual classroom because it creates several setbacks such as time management and variety. Organising and conducting formative assessment is also a major issue in the ESL classroom, especially those with huge groups of students because it will consume too much valuable time and student's assessment might be affected by the heavy interactions that might take place in the classroom (Lawrence, 2019). Hence, it becomes a major issue when a teacher wants to implement self-paced assessment in the classroom and then act according to the reports.

\section{Pedagogical Implications}

The implementation of self-paced assessment can cause major implications among teachers, especially ESL teachers in Malaysia. These implications en- 
compass two major categories which are training of ESL teachers and implications for stakeholders.

\subsection{Training of ESL Teachers}

In Malaysia, training of ESL teachers is tailored by closely referring to changes in the curriculum for schools and with the inclusion of CEFR in the English language curriculum, the training must focus exclusively on formative assessment methods in the classroom. Yet and Noordin (2017) mentioned how technology has become embedded in the ESL classroom and that pre-service ESL teachers need to be equipped with relevant skills that can allow them to organise and manage assessments more efficiently by using the available technologies. In terms of professional development, although studies like Pang (2017) and Omar, Rashid, Mohamad and Yusof (2017) have stated that ESL teachers take part in continuous in-service training, the rate of learning among teachers when it concerns the use of self-paced assessment is still low. Hence, there needs to be more inclusion of self-paced assessment topics in trainings of in-service and pre-service ESL teachers in Malaysia.

The pedagogical implications of self-paced assessment are vast as it will change how teachers design the lessons before and after each assessment is conducted. As discussed prior to this, before a lesson is conducted, considerations for self-paced assessment must be included in every lesson (Stover, Yearta, \& Harris, 2016). When each lesson is over, the teachers need to collect and analyse the self-paced assessments and the next lesson needs to be designed according to the reports. The idea of formative assessment is to inform the instructor and it must be reflected in the next lesson. McGlynn and Kelly (2017) agree that one significant implication is that the formative assessment methods in vocabulary instruction would create lessons which are inclusive for all types of learners.

\subsection{Stakeholders}

The research of the use of self-paced assessments in vocabulary instructions in the ESL classroom would impact the stakeholders in the schools. These stakeholders include administrators and parents who need to be made aware of the various elements in self-paced assessments. This is important as parents and administrators need to cooperate and support the self-paced assessment to help the teachers discover the rate of learning achieved by each learner. The school administrators need to structure instruction time that will be more suitable for the implementation of the various strategies of formative assessment. Parents need to support formative assessment strategies by providing more room for teachers to learn and explore each child's needs.

Speaking is a fundamental skill that needed to be acquired by language learners. It is very crucial for communicating. Without it, it is very tough to survive in the world that full of evolving technologies in which English is considered as the main language to communicate. According to Çakıroğlu (2018), speaking is "the 
process of building and sharing meaning in a variety of contexts using verbal and nonverbal signs". Whereas Lawrence (2019) has said that speaking is an interactive process of building meaning that includes constructing and receiving and processing information.

Chamot and O'malley (1987) define speaking as an example of a dynamic cognitive capacity that can be distinguished into many hierarchal sub-skills, some of which might need controlled processing while others just automated processing. According to Torres (2019), speaking is the most vital skill among four skills which are listening, speaking, reading, and writing. This is because a person who recognizes a language is called to as 'speaker of that language'. All in all, speaking skills are essential in expressing our thoughts, opinions, feelings and messages to each other.

Looking into Malaysian context, most ESL learners are not good in speaking due to little exposure to the language especially outside the classroom (Estaji \& Mirzaii, 2018). Speaking skills is always been a skill that overlooked by teachers because of the difficulty in teaching it. It is supported by González Fernández and Schmitt (2017) who stated that teaching communicative competences such as speaking, and listening are often overlooked by Malaysian teachers. In fact, according to Yunus and Sukri (2017), they agreed that Malaysian public standardized assessments only concentrate on reading and writing rather than listening and speaking.

The standardized examinations show that evaluation is very examination-oriented in the Malaysian context, resulting in pupils becoming passive recipients in the classroom without realizing that we are living at a time when the capability to speak English effortlessly has become an essential, particularly those who want to advance in certain areas of human endeavor. However, equal importance has started to give to speaking skills same as other skills after the implementation of new curriculum which is Common European Framework of Reference (CEFR) since the year 2017. Therefore, a suitable approach and teaching technique must be applied in order to improve the skill as Brysbaert, Stevens and Van Assche (2018) stressed that speaking ability remains a far-fetched target or an undefined subject believed to be impossible to achieve by pupils like other skills.

\section{Conclusion}

Conclusively, this concept paper conceptualises the idea of using self-paced assessment strategies in the ESL classroom in Malaysia. The idea is to experiment how the technique would impact the teaching and learning that occurs in the classroom. Thus, the use of self-paced assessment encourages ESL classroom leaners to learn vocabulary. In the field of education, self-paced formative assessment has become a great helper for teachers and students. In the future, this concept should be experimented using sound methodological designs that will provide more valuable data in the field of language research. For further re- 
search, it is recommended to do more research on the use of audio-visual materials in enhancing speaking skills to give more insight to teachers since most ESL learners have problems in speaking skills, for example, teaching and learning activities that can be done through this method, the criteria to be considered when selecting audio-visual materials could be given more focus for upcoming research.

\section{Acknowledgements}

The authors would like to thank Universiti Kebangsaan Malaysia under the Research Grant number 1) GGPM-2019-037 and 2) GG-2019-017 for supporting this project.

\section{Conflicts of Interest}

The authors declare no conflicts of interest regarding the publication of this paper.

\section{References}

Beck, I. L., McKeown, M. G., \& Kucan, L. (2002). Bringing Words to Life: Robust Vocabulary Instruction. New York, NY: Guilford Press Book/Childcraft International.

Broadbent, J., Panadero, E., \& Boud, D. (2018). Implementing Summative Assessment with a Formative Flavour: A Case Study in a Large Class. Assessment \& Evaluation in Higher Education, 43, 307-322. https://doi.org/10.1080/02602938.2017.1343455

Brysbaert, M., Stevens, M., \& Van Assche, E. (2018). Contextual Word Learning during Reading in a Second Language. Studies in Second Language Acquisition, 40, 341-366. https://doi.org/10.1017/S0272263117000109

Çakıroğlu, A. (2018). The Language Acquisition Approaches and the Development of Literacy Skills in Children. International Electronic Journal of Elementary Education, 11, 201-206. https://doi.org/10.26822/iejee.2019248600

Chamot, A. U., \& O'malley, J. M. (1987). The Cognitive Academic Language Learning Approach: A Bridge to the Mainstream. TESOL Quarterly, 21, 227-249. https://doi.org/10.2307/3586733

Dale, E., \& O’Rourke, J. (1981). The Living Word Vocabulary: A National Vocabulary Inventory. Chicago: World Book.

Ellis, R. (2010). Second Language Acquisition, Teacher Education and Language Pedagogy. Language Teaching, 43, 182-201. https://doi.org/10.1017/S0261444809990139

Estaji, M., \& Mirzaii, M. (2018). Enhancing EFL Learners' Vocabulary Learning through Formative Assessment: Is the Effort Worth Expending? Language Learning in Higher Education, 8, 239-264. https://doi.org/10.1515/cercles-2018-0015

Goldstein, H., Ziolkowski, R. A., Bojczyk, K. E., Marty, A., Schneider, N., Harpring, J., \& Haring, C. D. (2017). Academic Vocabulary Learning in First through Third Grade in Low-Income Schools: Effects of Automated Supplemental Instruction. Journal of Speech, Language, and Hearing Research, 60, 3237-3258. https://doi.org/10.1044/2017 JSLHR-L-17-0100

González Fernández, B., \& Schmitt, N. (2017). Vocabulary Acquisition. In S. Loewen, \& M. Sato (Eds.), The Routledge Handbook of Instructed Second Language Acquisition (pp. 280-298), New York, NY: Routledge. https://doi.org/10.4324/9781315676968-16 
Gu, Y., \& Johnson, R. (1996). Vocabulary Learning Strategies and Language Learning Outcomes. Language Learning, 46, 643-679. https://doi.org/10.1111/j.1467-1770.1996.tb01355.x

Guo, Y., Wang, S., Hall, A. H., Breit-Smith, A., \& Busch, J. (2016). The Effects of Science Instruction on Young Children's Vocabulary Learning: A Research Synthesis. Early Childhood Education Journal, 44, 359-367. https://doi.org/10.1007/s10643-015-0721-6

Halliday, M., Matthiessen, C. M., \& Matthiessen, C. (2014). An Introduction to Functional Grammar. London: Routledge. https://doi.org/10.4324/9780203783771

Haris, M., Yunus, M. M., \& Badusah, J. H. (2017). The Effectiveness of Using Padlet in ESL Classroom. International Journal of Advanced Research, 5, 783-788. http://dx.doi.org/10.21474/IJAR01/3214

Jalani, N. A. B. M., \& Hashim, H. B. (2020). Quizziz: ESL Students' Perceptions in Rural School. International Journal of Scientific and Research Publications, 10, 23-27. https://doi.org/10.29322/IJSRP.10.03.2020.p9904

Kepinska, O., de Rover, M., Caspers, J., \& Schiller, N. O. (2017). Whole-Brain Functional Connectivity during Acquisition of Novel Grammar: Distinct Functional Networks Depend on Language Learning Abilities. Behavioural Brain Research, 320, 333-346. https://doi.org/10.1016/j.bbr.2016.12.015

Ketabi, S., \& Ketabi, S. (2014). Classroom and Formative Assessment in Second/Foreign Language Teaching and Learning. Theory and Practice in Language Studies, 4, 435-440. https://doi.org/10.4304/tpls.4.2.435-440

Kintsch, W. (2007). Meaning in Context. In T. K. Landauer, D. S. McNamara, S. Dennis, \& W. Kintsch (Eds.), Handbook of Latent Semantic Analysis (pp. 89-106). Mahwah, NJ: Lawrence Erlbaum Associates.

Kreidler, C. W. (1979). Creating New Words by Shortening. Journal of English Linguistics, 13, 24-36. https://doi.org/10.1177/007542427901300102

Landauer, T. K., \& Dumais, S. T. (1997). A Solution to Plato's Problem: The Latent Semantic Analysis Theory of Acquisition, Induction, and Representation of Knowledge. Psychological Review, 104, 211-240. https://doi.org/10.1037/0033-295X.104.2.211

Lawrence, J. E. (2019). Teaching Large Classes: Engaging Students through Active Learning Practice and Interactive Lecture. International Journal of Teacher Education and Professional Development, 2, 66-80. https://doi.org/10.4018/IJTEPD.2019010105

Lee, S., \& Pulido, D. (2017). The Impact of Topic Interest, L2 Proficiency, and Gender on EFL Incidental Vocabulary Acquisition through Reading. Language Teaching Research, 21, 118-135. https://doi.org/10.1177/1362168816637381

Lim, C. K., Eng, L. S., Mohamed, A. R., \& Ismail, S. A. M. M. (2018). Relooking at the ESL Reading Comprehension Assessment for Malaysian Primary Schools. English Language Teaching, 11, 146-157. https://doi.org/10.5539/elt.v11n7p146

Maldonado-Mahauad, J., Pérez-Sanagustín, M., Moreno-Marcos, P. M., Alario-Hoyos, C., Muñoz-Merino, P. J., \& Delgado-Kloos, C. (2018). Predicting learners' Success in a Self-Paced MOOC through Sequence Patterns of Self-Regulated Learning. In V. Pammer-Schindler, M. Pérez-Sanagustín, H. Drachsler, R. Elferink, \& M. Scheffel (Eds.), European Conference on Technology Enhanced Learning (pp. 355-369). Cham: Springer. https://doi.org/10.1007/978-3-319-98572-5 27

McGlynn, K., \& Kelly, J. (2017). Using Formative Assessments to Differentiate Instruction. Science Scope, 41, 22-25. https://doi.org/10.2505/4/ss17 $041 \quad 04 \quad 22$

Moses, R. N., \& Mohamad, M. (2019). Challenges Faced by Students and Teachers on Writing Skills in ESL Contexts: A Literature Review. Creative Education, 10, 3385-3391. 
https://doi.org/10.4236/ce.2019.1013260

Nagy, W., Herman, P., \& Anderson, R. (1985). Learning Words from Context. Reading Research Quarterly, 20, 233-253. https://doi.org/10.2307/747758

Omar, R., Rashid, R. A., Mohamad, A., \& Yusof, N. (2017). A Review of Challenges for Professional Development of Malaysian Teachers. International Journal of Academic Research in Business and Social Sciences, 7, 809-815. http://dx.doi.org/10.6007/IJARBSS/v7-i7/3153

Oxford, R. L., \& Burry-Stock, J. A. (1995). Assessing the Use of Language Learning Strategies Worldwide with the ESL/EFL Version of the Strategy Inventory for Language Learning (SILL). System, 23, 1-23. https://doi.org/10.1016/0346-251X(94)00047-A

Pang, E. L. (2017). In-Service Education and Training (INSET): The Perceptions of English Language Teachers in Malaysia. Doctoral Dissertation, Coventry: University of Warwick.

Rubin, J. (1981). Study of Cognitive Processes in Second Language Learning. Applied Linguistics, 2, 117-131. https://doi.org/10.1093/applin/II.2.117

Sardareh, S. A. (2018). Formative Feedback in a Malaysian Primary School ESL Context. Malaysian Online Journal of Educational Sciences, 4, 1-8.

Stover, K., Yearta, L., \& Harris, C. (2016). Formative Assessment in the Digital Age: Blogging with Third Graders. The Reading Teacher, 69, 377-381.

https://doi.org/10.1002/trtr.1420

Torres, J. O. (2019). Positive Impact of Utilizing More Formative Assessment over Summative Assessment in the EFL/ESL Classroom. Open Journal of Modern Linguistics, 9, 1-11. https://doi.org/10.4236/ojml.2019.91001

Wang, F., \& Yamat, H. (2019). Identifying English Vocabulary Levels of Malaysia Year 5 Primary School Students. International Journal of Academic Research in Business and Social Sciences, 9, 62-76.

Yet, T. S., \& Noordin, N. B. (2017). The Use of ICT among Pre-Service English Language Teachers. International Journal of English Language Education, 5, 100-112. https://doi.org/10.5296/ijele.v5i1.10779

Yunus, M. M., \& Sukri, S. I. A. (2017). The Use of English in Teaching Mathematics and Science: The PPSMI Policy vis-à-vis the DLP. Advances in Language and Literary Studies, 8, 133-142. http://dx.doi.org/10.7575/aiac.alls.v.8n.1p.133

Zulkiflei, K., Yunus, M. M., \& Hashim, H. (2017). Positive Attitude Makes Good English. Really? International Conference on Education and Regional Development, 11. 